\title{
Kesiapan, Gaya Belajar dan Keaktifan Siswa Pada Pembelajaran Pendidikan Agama Islam di SMPN Bangkinang Kota
}

\author{
Muslim Afandi \\ Universitas Islam Negeri (UIN) Sultan Syarif Kasim Riau \\ muslm.afandi@uin-suska.ac.id \\ Zuraidah \\ Universitas Islam Negeri (UIN) Sultan Syarif Kasim Riau \\ zhuaida82@gmail.com
}

\begin{abstract}
This study aims to find out whether or not there is a significant influence of readiness and learning styles on students' learning activeness in Islamic education learning at state elementary schools in the district of Bangkinang Kota. This is a correlational study employing a quantitative approach. The study population amounted to 1529 students, and the samples were 317 students. The sampling deployed the Slovin formula with an error degree of 5\%. The sampling technique used proportionate stratified random sampling. Data collection techniques used questionnaires, observation, and documentation. The data analysis technique used multiple regression. The instruments used in this study had met the criteria of validity and reliability $\left(r_{1}=0.214\right.$ and $\left.r_{2}=0.254\right)$. The results showed that there was a significant influence of learning readiness on students' learning activeness; there was a significant influence of learning styles on students' learning activeness; and there was a significant influence of learning readiness and learning styles on students' learning activeness.
\end{abstract}

Keywords: Learning Readiness, Learning Styles, Learning Activeness

\begin{abstract}
Abstrak: Penelitian ini untuk mengetahui ada atau tidaknya pengaruh yang signifikan antara kesiapan dan gaya belajar terhadap keaktifan belajar siswa pada pembelajaran Pendidikan Agama Islam di SMPN Kecamatan Bangkinang Kota. Jenis penelitian ini kolerasi dengan pendekatan kuantitatif. Populasi penelitian ini berjumlah 1529 siswa. Sampel penelitian sebanyak 317 siswa. Pengambilan sampel menggunakan rumus Slovin dengan tingkat error 5\%. Teknik pengambilan sampel menggunakan Proportionate Stratified Random Sampling. Teknik pengumpuan data menggunakan angket, observasi dan dokumentasi. Teknik analisis data menggunakan regresi berganda. Instrumen yang digunakan dalam penelitian ini telah memenuhi kriteria valid dan reliabel $\left(r_{1}=0,214\right.$ dan $\left.r_{2}=0,254\right)$. Hasil penelitian menunjukkan bahwa terdapat pengaruh yang signifikan antara kesiapan belajar terhadap keaktifan belajar siswa; terdapat pengaruh yang signifikan antara gaya belajar dan keaktifan belajar siswa; dan terdapat pengaruh yang signifikan antara kesiapan belajar dan gaya belajar secara bersama-sama terhadap keaktifan belajar siswa.
\end{abstract}

Kata Kunci: Kesiapan Belajar, Gaya Belajar, Keaktifan Belajar

Belajea: Jurnal Pendidikan Islam Vol. 5, No 2, 2020; 221- 242

p-ISSN 2548-3390; e-ISSN 2548-3404, DOI:10.29240/belajea.v5i2.1551

http://journal.iaincurup.ac.id/indek.php/belajea 


\section{Pendahuluan}

Keaktifan siswa dalam belajar sangat diperlukan selama proses belajar mengajar sedang berlangsung ${ }^{1}$. Keaktifan belajar siswa dapat dilihat dari aktivitas yang dilakukannya, sebab pada prinsipnya belajar itu adalah berbuat "learning by doing". Learning by doing memiliki makna bahwa dalam belajar kita harus berbuat, dengan kata lain tidak disebut belajar kalau tidak ada aktivitas atau berbuat di dalamnya ${ }^{3}$. Selain itu, keaktifan siswa dalam belajar merupakan kegiatan selama proses pembelajaran yang mengaitkan kemapuan emosional dan fokus terhadap kreatifitas peserta didik ${ }^{4}$, dengan hal tersebut diharapkan dapat meningkatkan kemampuan dasarnya, menjadi peserta didik yang kreatif, menguasai ide-ide, mengembangkan diri, pemahaman dan berpikit tajam (kritis) serta interaksi sosial $^{5}$.

Keaktifan dalam kegiatan pembelajaran sangat bermacam-macam, mulai dari kegiatan yang mudah untuk diamati oleh guru (kegiatan fisik) sampai pada yang sulit untuk diamati oleh siapapun (kegiatan psikis) ${ }^{6}$. Bentuk kegiatan fisik yang dilakukan oleh peserta didik dalam proses belajar mengajar dapat berupa membaca buku bacaan, mendengarkan penjelasan yang disampaikan oleh guru, menulis catatan atau latihan, berlatih keterampilan-keterampilan tertentu dan lain sebagainya. Sedangkan contoh kegiatan psikis yang dilakukan oleh peserta didik dalam proses pembelajaran dapat berupa menggunakan pengetahuan yang dimilikinya dalam memecahkan suatu permasalahan yang ditampilkan oleh

\footnotetext{
${ }^{1}$ Ayuna Netta, "Peran Motivasi Bagi Siswa Dalam Proses Belajar-Mengajar,” Pedagogik: Jurnal Ilmiah Pendidikan Dan Pembelajaran Fakultas Tarbiyah Universitas Mubammadiyah Aceh 4, no. 2 (2017): 23-34.

2 Zahara Zahara, "Upaya Meningkatkan Hasil Belajar Siswa Melalui Penerapan Model Discovery Learning Pada Materi Komposisi Fungsi Dan Invers," Jurnal Kinerja Kependidikan (JKK) 1, no. 1 (2019): 88-104.

3 Ahmad Tanaka, "Sistem Among, Dalton, dan Shanti Niketan Kajian Komparatif Historikal Sistem Pendidikan Indonesia, Amerika, Dan India Serta Implikasinya Bagi Kemajuan Pendidikan Di Indonesia Konteks Kekinian," Jurnal Teknologi Pendidikan Madrasab 1, no. 1 (2018): 53-73; Tuti Nuriyati and Chanifudin Chanifudin, "Pendidik Millenial Di Era Globalisasi," Asatiza: Jurnal Pendidikan 1, no. 3 (2020): 361-372.

4 Idi Warsah, "Pendidikan Keimanan Sebagai Basis Kecerdasan Sosial Peserta Didik:Teaah psikologi Islami,” Psikis: Jurnal Psikologi Islami 4, no. 1 (2018): 1-16.

${ }^{5}$ Darfi Hani et al., "Active Learning Strategy Through Peer Lesson: An Effort to Instill Positive Behavior in Elementary School," Pedagogik Journal of Islamic Elementary School 3, no. 2 (October 20, 2020): 1-14, https://doi.org/10.24256/pijies.v3i2.1450; Idi Warsah, "Implementasi Nilai Kepedulian Sosial Dalam Pendidikan Karakter Melalui Interaksi Sosial," Jurnal Fakultas Agama Islam 9, no. 2 (2014).

${ }^{6}$ Salamah Salamah, "Peningkatan Proses Pembelajaran Pendidikan Agama Islam Melalui Penerapan Model Kooperatif Tipe Jigsaw dengan Menggunakan Media Video Zakir Naik," Belajea; Jurnal Pendidikan Islam 4, no. 1 (June 1, 2019): 75-102, https://doi.org/10.29240/belajea.v4i1.805.
} 
pendidik, membandingkan suatu konsep dengan konsep yang lainnya, menyimpulkan hasil percobaan yang dilakukan, dan sebagainya ${ }^{7}$.

Proses belajar merupakan proses yang komplek ${ }^{8}$. Sebagaimana yang telah dijelaskan sebelumnya dalam belajar harus diusahakan agar anak terlibat secara fisik dan mental, sehingga konsentrasinya dalam menyerap pelajaran dapat diupayakan secara maksimal. Apabila anak dapat terlibat secara penuh maka ia akan lebih aktif dalam belajar. Sebagaimana Allah berfirman dalam Al-qur'an Surah Al-Alaq ayat 1-5, ayat ini menjelaskan bahwa Allah SWT megajar manusia dengan perantara tulis baca dan interaksi antara pendidik dan peserta didik yang dilakukan oleh Allah SWT (sebagai seorang guru) kepada nabi Muhammad SAW (sebagai seorang murid) ${ }^{9}$. Hal ini berkaitan dengan aktifitas dan inovasi pendidik atau guru dalam proses pembelajarannya di kelas ${ }^{10}$.

Menurut Warsono dalam Yuliana dkk keaktifan belajar merupakan proses pembelajaran yang dilakukan seorang pendidik guna menghasilkan peserta didik yang aktif bertanya, mempertanyakan dan mengemukakan ide serta gagasannya ${ }^{11}$. Kegiatan pembelajaran akan berjalan dengan baik jika pendidik memberikan penjelasan dan latihan yang sesuai dengan kemampuan, pengetahuan dan pengalaman yang dimiliki oleh peserta didik ${ }^{12}$. Sehingga kegiatan pembelajaran haruslah dirancang sedemikian rupa oleh guru mata pelajaran, agar siswa dapat terlibat secara aktif baik dari segi fisik maupun psikis selama proses pembelajaran berlangsung ${ }^{13}$.

${ }^{7}$ Mudjiono Dimyati, Belajar \& Pembelajaran (Jakarta: Rineka Cipta, 2013). 45

8 Bambang Warsita, "Teori Belajar Robert M. Gagne Dan Implikasinya Pada Pentingnya Pusat Sumber Belajar," Jurnal Teknodik 12, no. 1 (2018): 064-078.

9 Idi Warsah, "Religious Educators: A Psychological Study of Qur'anic Verses Regarding al-Rahmah," AL QUDS : Jurnal Studi Alquran Dan Hadis 4, no. 2 (November 12, 2020): 275-98, https://doi.org/10.29240/alquds.v4i2.1762; Idi Warsah and Muhamad Uyun, "Kepribadian Pendidik: Telaah Psikologi Islami," Psikis: Jurnal Psikologi Islami 5, no. 1 June 18, 2019): 62-73, https://doi.org/10.19109/Psikis.v5i1.3157.

${ }^{10}$ Idi Warsah and Nuzuar Nuzuar, "Analisis Inovasi Administrasi Guru Dalam Meningkatkan Mutu Pembelajaran (Studi Man Rejang Lebong)," Edukasi 16, no. 3 (2018): 294572.

${ }^{11}$ Lisa Yuliana, Ikbal Barlian, and Riswan Jaenudin, "Pengaruh Model Pembelajaran Kooperatif Tipe Inside Outside Circle Terhadap Keaktifan Belajar Peserta Didik Pada Mata Pelajaran Ekonomi Kelas X Di SMA Srijaya Negara Palembang," Jurnal Profit Kajian Pendidikan Ekonomi Dan Imu Ekonomi 5, no. 1 (2018): 17-27.

12 Warsah, "Religious Educators"; Idi Warsah, Asri Karolina, and Yesa Satriya Dwi Hardiyanti, "Sense Of Humor Relevansinyaterhadap Teaching Style Telaah Psikologi Pendidikan Islam)," Ar-Risalab: Media Keislaman, Pendidikan Dan Hukum Islam 18, no. 2 (2020): 247-267.

${ }^{13}$ Siti Nusroh and Eva Luthfi, "Analisis Kesulitan Belajar Pendidikan Agama Islam (PAI) Serta Cara Mengatasinya," Belajea; Jurnal Pendidikan Islam 5, no. 1 (May 22, 2020): 71-92, https://doi.org/10.29240/belajea.v5i1.1145. 
Faktor yang mempengaruhi belajar dan memberikan dampak pada hasil belajar siswa terbagi menjadi dua, yaitu internal dan faktor eksternal. Faktor internal, yaitu faktor yang datang dari diri individu itu sendiri. Faktor eksternal, yaitu faktor yang mempengaruhi itu datang dari luar individu tersebut ${ }^{14}$. Faktorfaktor tersebut memberikan dampak pada jalannya kegiatan belajar mengajar diantaranya yaitu faktor kesiapan siswa dalam belajar dan faktor gaya belajar atau cara belajar. Dengan persiapan yang matang serta penggunaan gaya belajar yang cocok dan sesuai akan mempengaruhi kualitas siswa dalam belajar salah satunya selama proses pembelajaran menjadi lebih efektif dan bermakna ${ }^{15}$.

Intinya dibutuhkan kesiapan belajar siswa secara baik. Kesiapan merupakan suatu sikap siap siswa untuk melaksanakan sesuatu, kesediaan atau sikap siap yang dimiliki siswa untuk melakukan suatu kegiatan belajar sebelum kegiatan belajar mengajar di kelas dimulai merupakan bagian dari kesiapan belajar ${ }^{16}$. Cakupan pada kesiapan belajar ini terletak pada kemampuan siswa memposisikan diri dalam keadaan akan terjadinya suatu aktivitas baik dalam bentuk fisik maupun psikis.

Menurut teori belajar Koneksionisme, kesiapan merupakan salah satu hukum belajar. ${ }^{17}$ Maksud hukum belajar ini, bahwa seorang siswa akan merespon (menanggapi) dengan cepat dari setiap dorongan yang diberikan seorang guru jika dalam dirinya sudah memiliki kesediaan, sebaliknya jika dalam diri seseorang belum memiliki kesiapan, tidak mungkin seseorang dapat merespon setiap stimulus yang diberikan ${ }^{18}$. Dengan ada kesiapan dalam belajar diharapkan siswa akan menjadi lebih aktif selama proses belajar mengajar.

${ }^{14}$ Widia Hapnita, "Faktor Internal Dan Eksternal Yang Dominan Mempengaruhi Hasil Belajar Menggambar Dengan Perangkat Lunak Siswa Kelas XI Teknik Gambar Bangunan SMK N 1 Padang Tahun 2016/2017," CIVED (Journal of Civil Engineering and Vocational Education) 5, no. 1 (2018); Nugroho Dwi Ananto and Indira Januarti, “Analisis Faktor Internal Dan Eksternal Yang Mempengaruhi Persepsi Mahasiswa Akuntansi Terhadap Tindakan Plagiarisme Dengan Tekanan Sebagai Variabel Moderating," Diponegoro Journal of Accounting 5, no. 3 (2016).

${ }^{15}$ Hidayatul Muamanah and Suyadi, "Pelaksanaan Teori Belajar Bermakna David Ausubel Dalam Pembelajaran Pendidikan Agama Islam," Belajea; Jurnal Pendidikan Islam 5, no. 1 (May 22, 2020): 161-80, https://doi.org/10.29240/belajea.v5i1.1329.

${ }^{16}$ Muldiyana Nugraha, "Manajemen Kelas Dalam Meningkatkan Proses Pembelajaran," Tarbawi: Jurnal Keilmuan Manajemen Pendidikan 4, no. 01 (2018): 27-44.

17 Herman Albima, "Analisis Teori Behavioristik (Edward Thordinke) Dan Implementasinya Dalam Pembelajaran SD/MI," Modeling: Jurnal Program Studi PGMI 7, no. 1 (2020): 15-25.

${ }^{18}$ Wina Sanjaya, "Kurikulum Dan Pembelajaran: Teori Dan Praktik Pengembangan, KTSP". Jakarta: Kencana Prenada Media Group, 2009. 238 
Sedangkan gaya belajar atau cara belajar menurut Slameto dalam Saragih terdapat pada faktor eksternal yang mempengaruhi proses belajar mengajar ${ }^{19}$. Menggunakan gaya belajar yang cocok dan sesuai adalah perlu bagi siswa agar pembelajaran dapat diterima dan ditangkap dengan baik, serta siswa dapat belajar sesuai dengan gayanya sendiri dan belajar menjadi lebih menyenangkan. Nasution dalam Sibawaih mengatakan gaya belajar merupakan cara yang terusmenerus dilakukan seorang siswa dalam menerima stimulus dan informasi, mengingat, mengolah dan memecahkan suatu permasalahan ${ }^{20}$.

Porter dan Hernacki dalam Sartika mengemukakan cara belajar merupakan gabungan bagaimana seseorang menerima, mengatur serta mengolah informasi yang diterimanya ${ }^{21}$. Setiap individu memiliki cara belajar yang berbeda antara satu dan yang lainnya dalam mencapai hasil pembelajaran yang ditargetkannya. Apabila siswa menemukan cara belajar yang cocok dengan dirinya, maka proses belajar akan menjadi mudah dan menyenangkan bagi siswa tersebut. Karena setiap siswa memiliki cara yang berbeda dalam menyerap, mengolah serta memaknai pelajaran yang diterimanya ${ }^{22}$.

Beberapa macam cara belajar yang bisa digunakan diantaranya yaitu: belajar dengan cara melihat (visual), belajar dengan cara mendengar (auditori), dan belajar dengan cara bergerak dan sentuhan (kinestetik). ${ }^{23}$ Karekteristik individu belajar dengan cara melihat (visual) yaitu belajar dengan melihat gambar atau suatu objek, memiliki karakter rapi dan teratur, sulit menerima perintah lisan. Individu belajar dengan cara mendengar (auditori) memiliki karakteristik yaitu belajar dengan cara mendengar, terganggu oleh keributan dan keramaian, dan baik dalam kegiatan lisan. Cara belajar dengan cara bergerak dan sentuhan (kinestetik) memiliki karakteristik yaitu belajar dengan aktivitas tubuh, dan selalu

${ }^{19}$ Devi Kartika Saragih, "Pengaruh Kemandirian, Gaya Belajar Dan Lingkungan Belajar Terhadap Hasil Belajar Akuntansi Siswa Kelas X Program Keahlian Akuntansi SMK PGRI 3 Sidoarjo," Jurnal Ekonomi Pendidikan Dan Kewirausahaan 2, no. 1 (2017): 29-41.

${ }^{20}$ Imam Sibawaih and Anita Tri Rahayu, "Analisis Pola Asuh Orang Tua Terhadap Gaya Belajar Siswa Di Sekolah Menengah Atas Kharismawita Jakarta Selatan," Research and Development Journal of Education 3, no. 2 (2017).

${ }^{21}$ Cahya Dina Sartika, "Analisis Kemampuan Pemahaman Konsep Matematika Kelas V Ditinjau Dari Gaya Belajar Dan Jenis Kelamin” (PhD Thesis, UIN Raden Intan Lampung, 2020).

${ }^{22}$ Mutmainnah Amin, "Pengaruh Mind Map Dan Gaya Belajar Terhadap Hasil Belajar Matematika Siswa," Tadris: Jurnal Keguruan Dan Imu Tarbiyah 1, no. 1 (2016): 85-92.

${ }^{23}$ Joenita Darmawati, "Pengaruh Motivasi Belajar Dan Gaya Belajar Terhadap Prestasi Belajar Ekonomi Siswa SMA Negeri Di Kota Tuban," Jurnal Ekonomi Pendidikan Dan Kewirausabaan 1, no. 1 (2017): 79-90. 
menitik beratkan pada tubuh dan banyak bergerak, dan menghapal dan mengingat dengan cara bergerak ${ }^{24}$.

Pembelajaran pendidikan agama Islam saat ini bukanlah mata pelajaran utama khususnya pada sekolah-sekolah yang berlabel umum. Sehingga pelajaran ini tidak dianggap terlalu penting bagi sebagian siswa ${ }^{25}$. Sehingga selama proses pembelajaran siswa tidak menunjukkan keaktifannya, ditambah lagi dengan minimnya waktu yang disediakan untuk pembelajaran tersebut. Dengan adanya kesiapan belajar dan gaya belajar diharapkan dapat membantu meningkatkan keaktifan belajar siswa selama proses pembelajaran. Karena dengan adanya kesiapan belajar tersebut siswa siap untuk memberi respon atau bereaksi serta akan mempermudah siswa dalam menyerap pembelajaran yang diberikan seorang guru ${ }^{26}$.

Selain itu, pada pembelajaran PAI metode-metode lama masih selalu digunakan dalam menyampaikan materi pelajaran. Metode ceramah misanya seperti yang telah kita ketahui metode ceramah ini memiliki beberapa kelemahan ${ }^{27}$. Diantaranya, kurangnya partisipasi siswa dalam belajar, siswa mudah bosan, dan hanya mengandalkan ingatan. Melalui metode ceramah ini juga sangat sulit untuk mengetahui apakah seluruh siswa sudah mengerti apa yang dijelaskan atau belum, sehingga guru selalu melabel siswa A pintar dan siswa B bodoh, padahal guru hanya belum menggunakan pendekatan yang cocok untuk gaya belajar siswanya. Ditambah lagi dengan jam pelajaran yang diletakkan diakhir yang membuat siswa pada proses pembelajaran menjadi kurang fokus dengan ditemukan, selama proses pembelajaran berlangsung adanya sebagian siswa kurang memperhatikan penjelasan gurunya terkait materi pelajaran yang disampaikan ${ }^{28}$.

${ }^{24}$ Fathiya Eka Putri, Fitrah Amelia, and Yesi Gusmania, "Hubungan Antara Gaya Belajar Dan Keaktifan Belajar Matematika Terhadap Hasil Belajar Siswa," Edumatika: Jurnal Riset Pendidikan Matematika 2, no. 2 (2019): 83-88.

${ }^{25}$ Krismawati Krismawati, Idi Warsah, and Ummul Khair, "Implementasi Pendekatan Kontekstual Dalam Pembelajaran Pai Di Sekolah Dasar," Jurnal Elementaria Edukasia 3, no. 2 (October 22, 2020), https://doi.org/10.31949/jee.v3i2.2262.

${ }^{26}$ Rizqia Wardani, "Pengaruh Gaya Belajar, Kesiapan Belajar, Dan Kemampuan Numerik Terhadap Prestasi Belajar Matematika Siswa Smp," Ekuivalen-Pendidikan Matematika 30, No. 1 (2017).

${ }^{27}$ Vebri Angdreani, Idi Warsah, and Asri Karolina, "Implementasi Metode Pembiasaan: Upaya Penanaman Nilai-Nilai Islami Siswa SDN 08 Rejang Lebong," At-Ta'lim: Media Informasi Pendidikan Islam 19, no. 1 (2020): 1-21.

${ }^{28}$ Suryanto Suryanto, "Meningkatkan Prestasi Belajar Pelajaran IPS Melalui Gabungan Metode Ceramah Dengan Metode Belajar Aktif Model Pengajaran Autentik," Jurnal Visi Imu Pendidikan 10, no. 2 (2018): 135-146; Luluk Muasomah, "Metode Berprograma Dan Ceramah Pada Mata Pelajaran Fisika (Studi Kasus Pada Siswa Kelas 1 SMAN Ngrambe)," Al-Mabsut: Jurnal Studi Islam Dan Sosial 11, no. 2 (2017): 85-96. 
Jika masalah ini berlangsung secara terus-menerus, dikhawatirkan siswa tidak memiliki tujuan yang terarah selama pembelajaran serta tujuan pembelajaran tidak tersampaikan secara menyeluruh. Melihat kondisi inil peneliti ingin melihat kesiapan belajar dan gaya belajar siswa pada pembelajaran Pendidikan Agama Islam dihubungkan dengan keaktifan belajar siswa. Dengan adanya kesiapan belajar dan gaya belajar yang sesuai diharapan selama proses pembelajaran siswa menjadi lebih aktif dan pembelajaran menjadi lebih menyenangkan.

Berpijak pada penjelasan di atas dapat diketahui bahwa proses pembelajaran akan berjalan yang baik dengan didukung kesiapan belajar yang baik dan gaya belajar yang cocok dan sesuai. Dengan demikian situasi belajar akan efektif, kondusif dan terarahnya keaktifan belajar siswa secara baik, dengan melakukan kesiapan dalam belajar dan menemukan gaya belajar yang cocok, diharapkan selama proses pembelajaran dapat meningkatkan keaktifan belajar siswa. Sehingga siswa dapat ikut terlibat aktif dan berpartisipasi dalamnya. Timbal balik pada proses pembelajaran itu sangat diperlukan. Karena jika hanya guru yang berbicara di depan, siswa hanya mendengarkan saja, ini tidak akan efektif, karena belum tentu semua siswa paham akan materi yang dijelaskan guru. Namun jika siswa ikut terlibat dalam proses belajar, aktif bertanya, aktif menjawab dan memberi tanggapan, mengolah informasi maka hal ini akan membuat suasana belajar menjadi lebih efektif.

Berdasarkan studi pendahuluan yang telah penulis lakukan di SMPN Kecamatan Bangkinang Kota, yaitu SMPN 01 dan SMPN 02 Kecamatan Bangkinang Kota. pada tanggal 29 April dan 25 Juni 2019, ditemukan guru telah membantu siswa dalam kesiapan belajar dan menentukan gaya belajar sesuai dalam proses pembelajaran Pendidikan Agama Islam. Namun kenyataannya siswa masih belum menunjukkan keaktifannya dalam belajar. Penjelasan di atas menegaskan bahwa seyoganya jika guru telah melakukan usaha, maka akan meningkatkan keaktifan belajar siswa dalam proses pembelajaraan. Namun berdasarkan studi pendahuluan yang penulis lakukan ditemukan beberapa gejalagejala sebagai berikut: Masih ada siswa yang tidak bisa menjelaskan kembali materi kandungan Al-Qur'an terkait perilaku ikhlas, sabar dan pemaaf yang telah disampaikan oleh guru; Masih ada siswa yang tidak bisa menjawab ketika guru memberi pertanyaan hadist terkait materi perilaku ikhlas, sabar dan pemaaf; Masih ada siswa yang tidak mau bertanya ketika guru mempersilahkan untuk bertanya pada materi memahami hukum bacaan al-Quran; Masih ada siswa yang lebih banyak diam ketika proses pembelajaran berlangsung pada materi materi memahami hukum bacaan al-Quran; Masih adanya siswa yang kurang memperhatikan ketika guru menjelaskan materi pelajaran Pendidikan Agama Islam terkait pertumbuhan ilmu pengetahuan pada masa Bani Abbasiyah. Latar belakang dan gejala-gejala permasalahan di atas, penulis tertarik untuk 
melakukan penelitian terkait masalah tersebut studi ini ingin mengetahui apakah Kesiapan dan Gaya Belajar berpengaruh terhadap Keaktifan Belajar Siswa pada Pembelajaran Pendidikan Agama Islam di SMPN Kecamatan Bangkinang Kota”.

Penelitian ini merupakan penelitian lapangan (Field Research). Jenis penelitian ini kolerasi dengan pendekatan kuantitatif, Metode ini digunakan untuk mengetahui hubungan antara variabel bebas kesiapan belajar $\left(\mathrm{X}_{1}\right)$ dan gaya Belajar $\left(\mathrm{X}_{2}\right)$ terhadap variabel terikat keaktifan belajar $(\mathrm{Y})^{29}$. Lokasi Penelitian dilaksanakan di SMPN Kecamatan Bangkinang Kota yaitu SMPN 01 dan SMPN 01 Kecamatan Bangkinang Kota. Populasi pada penelitian ini berjumlah 1529 siswa. Sampel penelitan sebanyak 317 siswa. Pengambilan sampel dalam penelitian ini menggunakan rumus Slovin dengan tingkat error 5\%. Teknik pengambilan sampel menggunakan Proportionate Stratified Random Sampling. Teknik pengumpulan data dalam penelitian ini menggunakan angket sebagai perolehan data utama, observasi dan dokumentasi sebagai data pendkung. Instrumen yang digunakan dalam penelitian ini telah memenuhi kriteria valid dan reliable. Sedangkan teknik analisis data menggunakan regresi berganda.

\section{Hasil Dan Pembahasan}

\section{Paparan data hasil penelitian}

Untuk menguji hipotesis pertama dan kedua yaitu apakah ada Pengaruh antara Kesiapan Belajar(X1) terhadap Keaktifan Belajar (Y) dan antara Gaya Belajar(X2) terhadap Keatifan Belajar (Y) dapat dilihat pada tabel kolerasi dibawah ini dengan kriteria sebagai berikut:

Jika Probabilitas $>0.05 \mathrm{Maka}_{0}$ diterima;
Jika Probabilitas $<0.05$ Maka Ha diterima;

Tabel 1.

Rangkuman Hasil Uji Hipotesis

Korelasi Antara Variabel X1 dan X2 terhadap Y

Correlations

\begin{tabular}{llrrrr} 
& & & \multicolumn{2}{c}{ KEAKTIF } \\
& & \multicolumn{2}{c}{ KESIAPAN GAYA } & AN \\
& & BELAJAR & BELAJAR BELAJAR \\
KESIAPAN & Pearson Correlation & 1 &, $262^{* *}$ &, $621^{* *}$ \\
BELAJAR & Sig. (2-tailed) & &, 000 &, 000 \\
& N & 317 & 317 & 317 \\
GAYA BELAJAR & Pearson Correlation &, $262^{* *}$ & 1 &, $462^{* *}$
\end{tabular}

${ }^{29}$ Dominikus Dolet Unaradjan, Metode Penelitian Kuantitatif (Jakarta: Penerbit Unika Atma Jaya, 2019). 


\begin{tabular}{|c|c|c|c|c|}
\hline & Sig. (2-tailed) & 000 & & ,000 \\
\hline & $\mathrm{N}$ & 317 & 317 & 317 \\
\hline KEAKTIFAN & Pearson Correlation &, $621^{* *}$ &, $462^{* *}$ & 1 \\
\hline BELAJAR & Sig. (2-tailed) & 000 & ,000 & \\
\hline & $\mathrm{N}$ & 317 & 317 & \\
\hline
\end{tabular}

Hasil output dari tabel Colleration di atas menunjukkan bahwa korelasi antara variabel kesiapan belajar dan keaktifan belajar diperoleh $r=0,621$ dengan probabilitas $=0,000<0,05$, maka $\mathrm{H}_{0}$ ditolak dan $\mathrm{Ha}$ diterima yang berarti bahwa ada pengaruh yang sinifikan antara kesiapan belajar $\left(\mathrm{X}_{1}\right)$ dengan keaktifan belajar (Y). Sedangkan variabel gaya belajar dan kaktifan belajar diperoleh nilai $\mathrm{r}$ $=0,462$ dengan probabilitas $0,000<0,05$ maka $\mathrm{H}_{0}$ ditolak dan Ha diterima. Memiliki arti bahwa, ada pengaruh yang sinifikan antara gaya belajar $\left(\mathrm{X}_{2}\right)$ dengan keaktifan belajar $(\mathrm{Y})$.

Selanjutnya, untuk menguji hipotesis dari rumusan masalah yang ketiga apakah terdapat pengaruh antara Kesiapan Belajar $\left(\mathrm{X}_{1}\right)$ dan Gaya Belajar $\left(\mathrm{X}_{2}\right)$ secara bersama-sama terhadap keaktifan $(\mathrm{Y})$ dengan menggunakan uji $\mathrm{F}$ $(A N O V A)$ dengan Kriteria sebagai berikut:

Ha diterima bila Sig. $<0.05$

$\mathrm{H}_{0}$ ditolak bila Sig. $>0.05$

Untuk lebih jelasnya Hasil perhitungan Uji F (ANOVA) dapat dilihat pada tabel berikut ini:

\section{Tabel 2. \\ Uji F \\ ANOVA $^{a}$}

\begin{tabular}{|c|c|c|c|c|c|}
\hline Model & $\begin{array}{l}\text { Sum of } \\
\text { Squares }\end{array}$ & Df & $\begin{array}{l}\text { Mean } \\
\text { Square }\end{array}$ & $\mathrm{F}$ & Sig \\
\hline 1 Regression & 8419,015 & 2 & 4209,508 & 145,767 &, $000^{\mathrm{b}}$ \\
\hline Residual & 9067,824 & 314 & 28,878 & & \\
\hline Total & 17486,839 & 316 & & & \\
\hline
\end{tabular}

a. Dependent Variable: KEAKTIFAN BELAJAR

b. Predictors: (Constant), GAYA BELAJAR

, KESIAPAN BELAJAAR

Sumber: SPSS IBM Statistik, Ver. 22

Dari tabel output $A N O V A$ di atas dapat dijelaskan sebagai berikut:

1) Berdasarkan nilai signifikan (Sig.) dari tabel $A N O V A$ di atas diketahui bahwa nilai signifikan (Sig.) dalam uji $\mathrm{F}$ adalah 0,000. Karena nilai signifikan $0,000<0,05$, sebagaimana ketentuan dalam memutuskan uji $\mathrm{F}$ maka dapat disimpulkan bahwa $\mathrm{Ha}$ diterima, dengan artian kesiapan Belajar $\left(\mathrm{X}_{1}\right)$ dan 
Gaya Belajar $\left(\mathrm{X}_{2}\right)$ secara bersama-sama (simultan) berpengaruh terhadap Keaktifan Belajar Siswa (Y).

2) Berdasarkan perbandingan nilai $F_{\text {hitung }}$ dan $F_{\text {tabel, }}$, diketahui nilai $F_{\text {hitung }}$ adalah sebesar 145,7. Karena nilai $F_{\text {hitung }} 145,7>3,024$, sebagaimana ketentuan dalam pengambilan keputusan dalam uji $\mathrm{F}$ maka dapat disimpulkan bahwa Ha diterima dengan artian kesiapan belajar $\left(\mathrm{X}_{1}\right)$ dan gaya belajar $\left(\mathrm{X}_{2}\right)$ secara bersama-sama (simultan berpengaruh terhadap keaktifan belajar siswa $(\mathrm{Y})$.

Sedangkan uji regresi berganda merupakan suatu analisis yang digunakan untuk menguji sebesar apa pengaruh antara satu atau beberapa variabel bebas terhadap variabel terikat, baik sendiri-sendiri (parsial) maupun bersama-sama (simultan). Untuk mengetahui arah regresi berganda ketiga variabel dapat dilihat pada tabel berikut:

\title{
Tabel 3.
}

\section{Koefisien Persamaan Regresi Berganda}

\section{Coefficients $^{\mathrm{a}}$}

\author{
Unstandardized Standardized \\ Coefficients Coefficients
}

Std.

\begin{tabular}{|c|c|c|c|c|c|}
\hline Model & B & Error & Beta & $\mathrm{T}$ & $\underset{047}{\text { Sig. }}$ \\
\hline \multirow[b]{2}{*}{ ESIAPAN } & 7,082 & 3,551 & & 1,994 & ,047 \\
\hline & ,578 & ,045 & ,537 & 12,743 & , 000 \\
\hline $\begin{array}{l}\text { GAYA } \\
\text { BELAJAR }\end{array}$ & ,339 & ,044 & ,321 & 7,624 & , \\
\hline
\end{tabular}

a. Dependent Variable: KEAKTIFAN BELAJAR

Sumber: SPSS IBM Statistik, Ver. 22

Berdasarkan hasil output tabel di atas dapat dijelaskan sebagai berikut:

a. Ditemukan besar nilai kontanta 7,082; nilai kesiapan belajar $\left(\mathrm{X}_{1}\right)$ sebesar 0,578 dan nilai gaya belajar $\left(\mathrm{X}_{2}\right)$ sebesar 0,339 . Semua koefien tersebut signifikan karena masing-masing signifikannya $0,000(p<0,05)$. Sesuai dengan ketentuan sebelumnya maka $\mathrm{H}_{0}$ ditolak dan $\mathrm{H}_{\mathrm{a}}$ diterima, artinya ada pengaruh yang signifikan baik variabel kesiapan belajar atau gaya belajar dan Keaktifan Belajar Siswa pada Pembelajaran Pendidikan Agama Islam di SMPN Kecamatan Bangkinang Kota.

b. Ditemukan persamaan garis regresinya adalah:

$\mathrm{Y}=\alpha+\mathrm{b}_{1} \mathrm{X}_{1}+\mathrm{b}_{2} \mathrm{X}_{2}$ $\mathrm{Y}=7,082+0,578\left(\mathrm{X}_{1}\right)+0,339\left(\mathrm{X}_{2}\right)$

Persamaan regresi di atas dapat dijelaskan sebagai berikut: 
1) Ketetapat (konstanta) bernilai sebesar 7,082 , artinya jika kesiapan belajar $\left(\mathrm{X}_{1}\right)$ dan Gaya belajar $\left(\mathrm{X}_{2}\right)$ memiliki nilai 0 , maka keaktifan belajar $(\mathrm{Y})$ nilainya adalah 7,082 .

2) Koefisien regresi variabel kesipan belajar $\left(X_{1}\right)$ sebesar 0,578 artinya jika variabel bebas lain nilainya konstan dan kesiapan belajar mengalami kenaikan 1\% maka keaktifan belajar $(\mathrm{Y})$ akan mengalami kenaikan sebesar 0,578 .

3) Koefisien regresi variabel gaya belajar $\left(\mathrm{X}_{2}\right)$ sebesar 0,339 artinya jika variabel bebas lain nilainya konstan dan gaya belajar mengalami kenaikan $1 \%$ maka keaktifan belajar $(\mathrm{Y})$ akan mengalami peningkatan sebesar 0,339.

Untuk mengetahui besarnya persentase pengaruh kesiapan belajar dan gaya belajar terhadap keaktifan belajar siswa melalui tabel berikut ini:

\section{Tabel 4.}

Koefisien Determinasi (Besarnya Pengaruh X1 dan X2 terhadap Y)

\section{Model Summary}

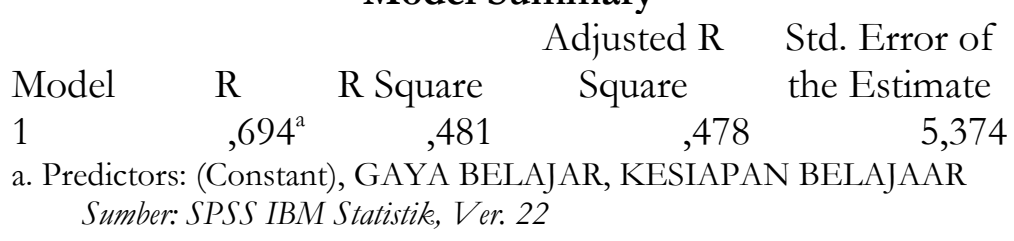

Berdasarkan tabel output Model Summary di atas dapat dipahami nilai koefisien determinasi atau $R$ Square adalah sebesar 0,481 , nilai $R$ Square 0,481 ini berasal dari kelipatan nilai koefisien korelasi $(\mathrm{R})$ yaitu $0,694 \times 0,694=0,481$. Angka koefisien determinasi sebesar 0,481 atau sama dengan 48,1\%. Angka tersebut memiliki arti bahwa variabel kesiapan belajar (X1) dan variabel gaya belajar (X2) secara bersama-sama (simultan) berpengaruh terhadap terhadap variabel keaktifan belajar siswa (Y) sebesar 48,1\%. Sedangkan 51,9\% sebagai sisanya dipengaruhi oleh faktor lain atau diluar variabel yang diteliti.

\section{Pembahasan}

\section{Kesiapan Belajar}

Kesiapan belajar adalah faktor penting yang harus dilakukan dalam proses belajar mengajar. Seorang siswa yang memiliki kesiapan yang baik dalam belajar hasil yang didapatkan akan lebih maksimal dibandingkan dengan hasil seorang siswa yang tidak memiliki kesiapan sama sekali. Selain itu dengan adanya kesiapan dalam belajar siswa lebih mudah mengikuti proses pembelajaran.

Menurut Drever dalam Kurnila kesiapan merupakan "Preparedness to respond or react" bermaksud bahwa kesediaan seseorang individu untuk memberi 
jawaban atau tanggapan. ${ }^{30}$ Dengan artian kesiapan belajar perlu diperhatikan selama proses pembelajaran agar memperoleh hasil yang lebih baik dalam belajar. Karena jika siswa dalam kondisi siap dan sedia dalam proses pembelajaran maka siswa cenderung lebih mudah mengikuti pembelajaran. Terbukti dalam paparan data hasil penelitian bahwa kesiapan belajar menjadi faktor penentu dalam keberhasilan belajar siswa.

Kondisi fisik siswa, mental, emosional, kebutuhan dan pengetahuan digunakan sebagai dasar indikator kesiapan belajar pada penelitian ini. Pendengaran, penglihatan, kesehatan tergolong pada kondisi fisik. Kepercayaan dan penyesuaian diri sendiri masuk pada kondisi mental. Permasalahan dan ketegangan termasuk pada kondisi emosional. Ketersedian sumber, alat dan bahan pelajaran, perlengkapan termasuk pada kebutuhan. Mendapatkan informasi dengan membaca buku pelajaran, berita di media cetak termasuk pada pengetahuan. Berdasarkan keterangan di atas dapat disimpulkan kesiapan belajar merupakan kondisi siswa yang siap dan penuh dengan kesadaran untuk melaksanakan suatu kegiatan untuk memperoleh informasi, pemahaman, skill, nilai dan sikap melalui pengamatan, mencontohkan, berlatih, menyelidiki, dan dengan mendapatkan pengetahuan baru.

Kesiapan peserta didik dalam belajar dapat mempengaruhi proses belajar. menyelesaikan suatu tugas dalam belajar seseorang siswa akan mengalami kesulitan bahkan putus asa jika seseorang tersebut belum memiliki kesiapan. Prinsif kesiapan ini meliputi: a) Petumbuhan fisik dan Kematangan; b) Intelegensi; c) pengalaman yang dimiliki; d) Hasil belajar; e) dorongan (motivasi); f) sudut pandang dan faktor lain yang membuat seseorang seseorang dapat belajar. ${ }^{31}$

Kondisi siswa yang siap akan memberikan dampak positif bagi siswa saat menerima pelajaran dari guru. Siswa akan merespon pertanyaan dan memberikan gambaran tentang keterkaitan materi yang telah lalu dan yang akan diajarkan jika siswa memiliki kesiapan belajar. Karena melalui kesiapan belajar dapat memotivasi siswa untuk memahami apa yang telah diajarkan guru.

\section{Gaya Belajar}

Gaya belajar mempengaruhi cara seseorang menyerap dan mengolah informasi yang diterimanya. Karena antara siswa A, siswa B dan Siswa lainnya menggunakan cara yang berbada. Gaya belajar merupakan cara termudah yang bisa dan biasa dilakukan peserta didik dalam menerima suatu informasi. Kunci keberhasilah yang ingin dicapai peserta didik dalam belajar terletak pada gaya

30 Rima Kurnia, Sany Dwita, and Salma Taqwa, "Pengaruh Motif dan Kesiapan Terhadap Hasil Belajar Pengantar Akuntansi 1," Jurnal Eksplorasi Akuntansi 1, no. 2 (2019): 556571.

${ }^{31}$ Karnowo dan Heni Mularsih, Belajar dan Pembelajaran, (Depok: PT. Raja Grafindo Persada, 2018), h. 34 
belajar yang sesuai denga dirinya. Menyadari hal tersebut menjadikan peserta didik mampu menerima dan mengolah informasi dengan mudah menggunakan cara belajarnya sendiri.

Menurut Nasution gaya belajar merupakan cara yang digunakan peserta didik secara terus menerus dalam menerima, mengingat, mengolah dan memecahkan suatu persoalan ${ }^{32 .}$ Pada dasarnya untuk mendapatkan hasil yang baik dalam mencapai target yang ditentukan setiap peserta didik memiliki cara belajar yang berbeda antara satu dan yang lainnya. Jika peserta didik menemukan cara belajar yang cocok untuk dirinya, belajar akan menjadi mudah baginya. Karena setiap peserta didik memiliki cara yang berbeda dalam mengolah informasi serta bagaimana memaknai informasi yang diterimanya ${ }^{33}$.

Berdasarkan penjelasan di atas dapat diambil kesimpulan bahwa gaya belajar merupakan suatu cara yang dipilih seorang peserta didik yang lebih disukai dan merasa lebih efektif dalam melaksanakan aktivitas berpikir, mengolah dan memahami suatu materi pelajaran. Antara peserta didik satu dengan peserta didik lainnya masing-masing memiliki cara belajar yang tidak sama, meskipun kedua perserta didik tersebut tumbuh dalam keadaan, tempat, dan perlakuan yang sama.

Gaya belajar menjadi faktor penting dalam meningkatkan kinerja pada pekerjaan di sekolah, dan antar pribadi. Cara belajar seorang siswa adalah gabungan dari bagaimana ia menerima, dan kemudian mengolah informasi yang diterima. Menurut Bobbi De Porter dalam Mentari, ia mengemukakan, bahwa gaya belajar ada 3 macam, yaitu visual (belajar dengan cara melihat), auditorial (belajar dengan cara mendengar) dan kinestetik (belajar dengan cara bergerak) ${ }^{34}$.

1) Belajar dengan cara melihat (visual), Porter, mengatakan ciri-ciri orang belajar dengan cara melihat adalah sebagai berikut: Rapi baik tulisan maupun penampilan; sistematis; berbicara cepat; perencana yang handal; manajemen yang baik; jeli dan sangat terperinci; Memprioritaskan penampilan dalam hal pakaian dan penampilan; Pengeja yang baik; mampu mengeluarkan dan menggambarkan ide-ide yang mereka pikirkan; mengingat yang dilihat; daripada didengar; mudah mengingat dengan asosiaso gambar; tidak terganggu dengan keramaian; lemah dalam intruksi lisan dan selalu minta untuk diulangin; cepat dan tekun dalam membaca; senang membaca sendiri daripada dibacakan; bersikap waspada; mencoret dan menulis tanpa arti

32 Sibawaih and Rahayu, "Analisis Pola Asuh Orang Tua Terhadap Gaya Belajar Siswa Di Sekolah Menengah Atas Kharismawita Jakarta Selatan."

33 Putri, Amelia, and Gusmania, "Hubungan Antara Gaya Belajar Dan Keaktifan Belajar Matematika Terhadap Hasil Belajar Siswa."

${ }^{34}$ Nia Mentari, Hepsi Nindiasari, and Aan Subhan Pamungkas, "Analisis Kemampuan Berpikir Reflektif Siswa SMP Berdasarkan Gaya Belajar,” NUMERICAL: Jurnal Matematika Dan Pendidikan Matematika, 2018, 31-42. 
selama berbicara ditelepon dan dalam pertemuan; lupa menyampaiakn pesan dalam bentuk lisan; menjawab pertanyaan dengan singkat; senang melakukan peragaan daripada menjelaskan; menyukai seni dibandingkan musik; tau apa yang harus disampaikan namun tidak pandai mengatakannya; mudah kehilangan konsentrasi ketika ingin fokus ${ }^{35}$.

2) Belajar dengan cara mendengar (auditorial), Porter mengatakan, ciri-ciri orang belajar dengan cara mendengarkan adalah sebagai berikut: berkomunikasi pada diri sendiri; terganggu pada keramaian; menggerakkan bibir ketika menyebutkan tulisan di buku saat membaca; membaca keras dan mendengarkan; mampu me-review apa yang didengar; sulit dalam menulis, namun baik dalam berbicara dan bercerita; pembicara yang fasih dan terpola; menyukai musik daripada seni; belajar dengan cara mengingat apa yang didengar dan didiskusikan; panjang lebar dalam menjelaskan sesuatu; lemah dalam melihat (visualisasi); pandai mengeja daripada menuliskannya; daripada membaca komik lebih menyukai gurauan lisan ${ }^{36}$.

3) Belajar dengan cara bergerak (Kinestetik), gaya belajar ini adalah belajar dengan cara bergerak, bekerja dan menyentuh. Porter, mengatakan ciri-ciri orang belajar dengan cara bergerak adalah sebagai berikut: lambat jika berbicara; merespons perhatian fisik; untuk mendapatkan perhatian dilakukan dengan sentuhan; berdiri dekat dengan lawan bicara; cenderung pada fisik dan bergerak; awal perkembangan otot yang besar; belajar melalui rekayasa dan mengerjakan langsung; mengingat dengan berjalan-jalan dan memperhatikan; menunjuk menggunakan jari ketika membaca; memakai gesture tubuh; tidak duduk untuk durasi yang lama; sulit mengingat tempat; menggunakan kata yang mengarahkan pada tindakan; menyukai buku menggambarkan aksi dengan gerakan tubuh; memiliki tulisan yang buruk; suka mencoba hal baru; senang pada permainan aktifitas fisik ${ }^{37}$.

Belajar melalui apa yang mereka lihat termasuk pada gaya belajar jenis visual, belajar dari apa yang mereka dengar termasuk pada gaya belajar jenis auditorial, sedangkan belajar dari gerak dan sentuhan mereka termasuk pada gaya belajar kinestetik. Satu cara belajar biasanya lebih mendominasi pada diri peserta didik, walaupun setiap peserta didik memiliki ketiga gaya belajar tersebut ${ }^{38}$.

Beberapa peserta didik misalnya dapat belajar dengan baik apabila keadaan sunyi dan sepi, sedang sebagian yang lain tetap bisa belajar meskipun

35 Mentari, Nindiasari, and Pamungkas.

${ }^{36}$ Mentari, Nindiasari, and Pamungkas.

${ }^{37}$ Mentari, Nindiasari, and Pamungkas.

38 Arylien Ludji Bire, Uda Geradus, and Josua Bire, "Pengaruh Gaya Belajar Visual, Auditorial, Dan Kinestetik Terhadap Prestasi Belajar Siswa," Jurnal Kependidikan: Penelitian Inovasi Pembelajaran 44, no. 2 (2014). 
tidak dalam kesunyian bahkan sambil mendengarkan beberapa musik. Beberapa peserta didik merasa belajar paling baik adalah dengan cara berkelompok, ada sebagian peserta didik memilih adanya sosok yang mengarahkan atau menuntun seperti orangtua atau guru. Oleh karena itu, setiap guru harus memperhatikan sikapnya di hadapan siswa baik dalam proses belajar di kelas maupun di tengahtengah masyarakat ${ }^{39}$.Sedangkan sebagian peserta didik lain merasa belajar sendiri adalah cara yang paling efektif bagi mereka. Sebagian orang memerlukan tempat belajar yang rapi dan teratur, tetapi sebagian yang lain lebih suka meletakkan segala sesuatu agar lebih mudah terlihat.

\section{Keaktifan Belajar}

Keaktifan belajar adalah unsur dasar utama dalam keberhasilan proses pembelajaran $^{40}$. Keaktifan siswa dalam belajar adalah segala aktifitas atau prilaku siswa baik bersifat fisik maupun psikis dalam proses kegiatan belajar mengajar yang berperan aktif secara optimal. Sehingga dengan keaktifan belajar tersebut dapat menciptakan suasana kelas yang mendukung jalannya proses pembelajaran. ${ }^{41}$ Oleh karena itu hal tersebut menjadi usaha guru dalam mengaktifkan perilaku siswa selama proses belajar mengajar.

Berpijak pada penjelasan di atas dapat disimpulkan bahwa keaktifan belajar siswa dapat dilihat melalui berbagai aktifitas selama proses belajar mengajar sedang berlansung, misalnya, memperhatikan dan mendengarkan saat guru memberikan penjelasan, berdiskusi dalam kelompok, mengajukan pertanyaan, keberanian mengemukakan ide dan gagasan dan mampu memecahkan suatu persoalan.

Paul B. Diedrich menyebutkan macam-macam aktifitas yang meliputi jasmani dan jiwa, antara lain sebagai berikut:

1) Aktifitas memperhatikan (Visual), misalnya, kegiatan melihat suatu objek, membaca, melakukan demonstrasi, eksperimen, pekerjaan orang lain dan sebagainya.

2) Aktifitas berbicara (Oral), misalnya, mengemukakan atau menyampaikan suatu hal, merumuskan, mengajukan pertanyaan, memberi saran dan masukan, serta mengeluarkan pendapat.

3) Aktifitas Mendengar (Listening), misalnya, mendengarkan suatu penjelasan, percakapan diskusi, musik, ceramah dan sebagainya.

${ }^{39}$ Warsah and Uyun, "Kepribadian Pendidik."

40 Nugroho Wibowo, "Upaya Peningkatan Keaktifan Siswa Melalui Pembelajaran Berdasarkan Gaya Belajar Di SMK Negeri 1 Saptosari," Elinvo (Electronics, Informatics, and Vocational Education) 1, no. 2 (2016): 128-139; Mukhlison Effendi, "Integrasi Pembelajaran Active Learning Dan Internet-Based Learning Dalam Meningkatkan Keaktifan Dan Kreativitas Belajar," Nadwa 7, no. 2 (2016): 283-309.

${ }^{41}$ Wibowo, "Upaya Peningkatan Keaktifan Siswa Melalui Pembelajaran Berdasarkan Gaya Belajar Di SMK Negeri 1 Saptosari.” 
4) Aktifitas menulis (Writing), misalnya, menulis cerita, membuat karangan, membuat laporan, membuat pertanyaan, mencatat dan sebagainya.

5) Aktifitas (Drawing), misalnya, menggambar suatu objek, membuat pola, grafik, peta dan sebagainya.

6) Aktifitas gerak (Motor), misalnya, melakukan eksperimen, membuat bangunan, bermain, berkerja, menjaga hewan peliharaan dan sebagainya.

7) Aktifitas pola pikir (Mental), misalnya, menerima,menghafal, memecahkan persoalan, menelaah, memutuskan dan sebagainya.

8) Aktifitas jiwa (Emotional), misalnya, menaruh minat pada suatu hal, suka, bahagia, percaya diri, tenang, gugup, kagum, marah dan sebagainya ${ }^{42}$.

Dari penjelasan di atas, dapat ketahui bahwa seorang siswa dalam belajar harus bekerja sendiri agar siswa tersebut memiliki potensi untuk mengembangkan dan membentuk dirinya sendiri. Adapun peran seorang guru adalah mengawasi dan membantu bagaimana proses pertumbuhan anak didiknya. Bekerja sendiri yang dimaksudkan di sini adalah berpikir dan berbuat sendiri.

Adapun ciri-ciri peserta didik yang aktif dalam pembelajaran adalah sebagai berikut:

1) Siswa akan mengajukan pertanyaan dan meminta penjelasan dari gurunya, apabila ada persoalan dan materi pelajaran yang belum dipahami dan belum dapat dipecahkan

2) Siswa menyampaikan pendapat dan mendiskusikan gagasan orang lain dengan cara dan gagasannya sendiri.

3) Siswa yang aktif dalam belajar harus gesif, bersemangat dan penuh gairah. Siswa mengerjakan semua tugas yang diberikan menggunakan kemampuan berpikirnya, menelaah suatu gagasan, memecahkan permasalahan dan mengaplikasikan apa yang telah mereka dapatkan dari prses pembelajaran dalam kehidupan mereka. ${ }^{43}$

Indikator keaktifan belajar yang digunakan dalam penelitian ini adalah sebagai berikut: a) Pemecahan masalah, yang meliputi: Menyelesaikan suatu masalah dengan mencari pada referensi dan sumber lain; ketika ada persoalan dan kesulitan dalam pembelajaran siswa bertanya kepada guru; siswa bertanya kepada teman yang lebih paham ketika dalam mengerjakan tugas ada kesulitan. b) Kerjasama, meliputi: menghargai jika terdapat perbedaan pendapat; bekerjasama dan berpartisipasi dengan baik dalam kelompok; mengikuti secara aktif kegiatan kelompok dalam memecahkan suatu masalah. c) Mengemukakan gagasan, meliputi: menanggapi pertanyaan atau instruksi dari guru; percaya diri menyampaikan atau memaparkan hasil temuan; percaya diri dalam

42 Abdul Wahab Ramayulis, Ilmu Pendidikan Islam (Jakarta: Kalam Mulia, 2008). 243-244.

${ }^{43}$ Melvin L. Silberman, "Active Learning 101 Cara Belajar Siswa Aktif Edisi Revisi," (Bandung: Nuansa Cendekia, 2013). 9 
mengemukakan pendapat dan gagasan. d) Perhatian, meliputi: memperhatikan dan mendengarkan materi yang guru sampaikan, mencatat materi yang guru berikan dengan lengkap dan rapi; fokus dalam mengikuti proses belajar mengajar; mengikuti jalannya proses pembelajaran di dalam kelas.

\section{Penutup}

Berdasarkan hasil analisis yang telah dilakukan, maka dapat diambil kesimpulan sebagai berikut:

1. Terdapat pengaruh yang signifikan antara kesiapan belajar terhadap keaktifan belajar Pada Pembelajaran Pendidikan Agama Islam di SMPN Kecamatan Bangkinang Kota. Dengan diperoleh $\mathrm{r}=0,621$ dengan probabilitas $=0,000<$ 0,05, maka $\mathrm{H}_{0}$ ditolak dan $\mathrm{Ha}$ diterima. Hal ini berarti dengan adanya peningkatan kesiapan belajar yang baik akan meningkatkan keaktifan belajar siswa Pada Pembelajaran Pendidikan Agama Islam di SMPN Kecamatan Bangkinang Kota.

2. Terdapat pengaruh yang signifikan antara gaya belajar terhadap keaktifan belajar Pada Pembelajaran Pendidikan Agama Islam di SMPN Kecamatan Bangkinang Kota. Dengan $\mathrm{r}=0,462$ dengan probabilitas 0,000 $<0,05$ maka $\mathrm{H}_{0}$ ditolak dan $\mathrm{Ha}$ diterima. Hal ini berarti dengan adanya penggunaan gaya belajar yang cocok maka akan meningkatkan keaktifan belajar siswa Pada Pembelajaran Pendidikan Agama Islam di SMPN Kecamatan Bangkinang Kota.

3. Terdapat pengaruh yang signifikan antara kesiapan dan gaya belajar terhadap keaktifan belajar siswa Pada Pembelajaran Pendidikan Agama Islam di SMPN Kecamatan Bangkinang Kota. Dengan nilai signifikan (Sig.) dalam uji F (ANOVA) adalah 0,000. Karena nilai signifikan 0,000 $<0,05$, maka $\mathrm{Ha}$ diterima dan $\mathrm{H}_{0}$ ditolak. Hal ini berarti dengan adanya kesiapan belajar yang baik dan penggunaan cara belajar yang sesuai maka akan dapat meningkatkan keaktifan belajar siswa Pada Pembelajaran Pendidikan Agama Islam di SMPN Kecamatan Bangkinang Kota.

\section{Bibliografy}

Albima, Herman. "Analisis Teori Behavioristik (Edward Thordinke) dan Implementasinya dalam Pembelajaran SD/MI." Modeling: Jurnal Program Studi PGMI 7, no. 1 (2020): 15-25.

Amin, Mutmainnah. "Pengaruh Mind Map dan Gaya Belajar Terhadap Hasil Belajar Matematika Siswa." Tadris: Jurnal Keguruan dan Ilmu Tarbiyah 1, no. 1 (2016): 85-92. 
Ananto, Nugroho Dwi, and Indira Januarti. "Analisis Faktor Internal dan Eksternal Yang Mempengaruhi Persepsi Mahasiswa Akuntansi Terhadap Tindakan Plagiarisme dengan Tekanan Sebagai Variabel Moderating." Diponegoro Journal of Accounting 5, no. 3 (2016).

Angdreani, Vebri, Idi Warsah, and Asri Karolina. "Implementasi Metode Pembiasaan: Upaya Penanaman Nilai-Nilai Islami Siswa SDN 08 Rejang Lebong." At-Ta'lim: Media Informasi Pendidikan Islam 19, no. 1 (2020): $1-$ 21.

Bire, Arylien Ludji, Uda Geradus, and Josua Bire. "Pengaruh Gaya Belajar Visual, Auditorial, dan Kinestetik Terhadap Prestasi Belajar Siswa." Jurnal Kependidikan: Penelitian Inovasi Pembelajaran 44, no. 2 (2014).

Darmawati, Joenita. "Pengaruh Motivasi Belajar dan Gaya Belajar Terhadap Prestasi Belajar Ekonomi Siswa SMA Negeri di Kota Tuban." Jurnal Ekonomi Pendidikan Dan Kewirausahaan 1, no. 1 (2017): 79-90.

Dimyati, Mudjiono. Belajar \& Pembelajaran (Jakarta: Rineka Cipta, 2013).

Effendi, Mukhlison. "Integrasi Pembelajaran Active Learning Dan InternetBased Learning Dalam Meningkatkan Keaktifan Dan Kreativitas Belajar." Nadwa 7, no. 2 (2016): 283-309.

Hani, Darfi, Sugiatno Sugiatno, Rini Rini, and Idi Warsah. "Active Learning Strategy Through Peer Lesson: An Effort to Instill Positive Behavior in Elementary School." Pedagogik Journal of Islamic Elementary School 3, no. 2 (October 20, 2020): 1-14. https://doi.org/10.24256/pijies.v3i2.1450.

Hapnita, Widia. "Faktor Internal dan Eksternal yang Dominan Mempengaruhi Hasil Belajar Menggambar dengan Perangkat Lunak Siswa Kelas XI Teknik Gambar Bangunan SMK N 1 Padang Tahun 2016/2017." CIVED (Journal of Civil Engineering and Vocational Education) 5, no. 1 (2018).

Krismawati, Krismawati, Idi Warsah, and Ummul Khair. "Implementasi Pendekatan Kontekstual Dalam Pembelajaran PAI di Sekolah Dasar." Jurnal Elementaria Edukasia 3, no. 2 (October 22, 2020). https://doi.org/10.31949/jee.v3i2.2262.

Kurnia, Rima, Sany Dwita, and Salma Taqwa. "Pengaruh Motif Dan Kesiapan Terhadap Hasil Belajar Pengantar Akuntansi 1." Jurnal Eksplorasi Akuntansi 1, no. 2 (2019): 556-571. 
Mentari, Nia, Hepsi Nindiasari, and Aan Subhan Pamungkas. "Analisis Kemampuan Berpikir Reflektif Siswa SMP Berdasarkan Gaya Belajar." Numerical: Jurnal Matematika Dan Pendidikan Matematika, 2018, 31-42.

Muamanah, Hidayatul, and Suyadi. "Pelaksanaan Teori Belajar Bermakna David Ausubel Dalam Pembelajaran Pendidikan Agama Islam." Belajea; Jurnal Pendidikan Islam 5, no. 1 (May 22, 2020): 161-80. https://doi.org/10.29240/belajea.v5i1.1329.

Muasomah, Luluk. "Metode Berprograma dan Ceramah pada Mata Pelajaran Fisika (Studi Kasus Pada Siswa Kelas 1 SMAN Ngrambe)." Al-Mabsut: Jurnal Studi Islam Dan Sosial 11, no. 2 (2017): 85-96.

Netta, Ayuna. "Peran Motivasi Bagi Siswa Dalam Proses Belajar-Mengajar." Pedagogik: Jurnal Ilmiah Pendidikan Dan Pembelajaran Fakultas Tarbiyah Universitas Mubammadiyah Aceh 4, no. 2 (2017): 23-34.

Nugraha, Muldiyana. "Manajemen Kelas dalam Meningkatkan Proses Pembelajaran." Tarbawi: Jurnal Keilmuan Manajemen Pendidikan 4, no. 01 (2018): 27-44.

Nuriyati, Tuti, and Chanifudin Chanifudin. "Pendidik Millenial di Era Globalisasi." Asatiza: Jurnal Pendidikan 1, no. 3 (2020): 361-372.

Nusroh, Siti, and Eva Luthfi. "Analisis Kesulitan Belajar Pendidikan Agama Islam (PAI) Serta Cara Mengatasinya." Belajea; Jurnal Pendidikan Islam 5, no. 1 (May 22, 2020): 71-92. https://doi.org/10.29240/belajea.v5i1.1145.

Putri, Fathiya Eka, Fitrah Amelia, and Yesi Gusmania. "Hubungan Antara Gaya Belajar Dan Keaktifan Belajar Matematika Terhadap Hasil Belajar Siswa." Edumatika: Jurnal Riset Pendidikan Matematika 2, no. 2 (2019): 8388.

Ramayulis, Abdul Wahab. Ilmu Pendidikan Islam (Jakarta: Kalam Mulia, 2008).

Salamah, Salamah. "Peningkatan Proses Pembelajaran Pendidikan Agama Islam Melalui Penerapan Model Kooperatif Tipe Jigsaw dengan Menggunakan Media Video Zakir Naik." Belajea; Jurnal Pendidikan Islam 4, no. 1 (June 1, 2019): 75-102. https://doi.org/10.29240/belajea.v4i1.805.

Sanjaya, Wina, Kurikulum Dan Pembelajaran: Teori Dan Praktik Pengembangan, KTSP (Jakarta: Kencana Prenada Media Group, 2009).

Saragih, Devi Kartika. "Pengaruh Kemandirian, Gaya Belajar Dan Lingkungan Belajar Terhadap Hasil Belajar Akuntansi Siswa Kelas X Program 
Keahlian Akuntansi SMK PGRI 3 Sidoarjo." Jurnal Ekonomi Pendidikan Dan Kewirausahaan 2, no. 1 (2017): 29-41.

Sartika, Cahya Dina. "Analisis Kemampuan Pemahaman Konsep Matematika Kelas V Ditinjau Dari Gaya Belajar Dan Jenis Kelamin.” PhD Thesis, UIN Raden Intan Lampung, 2020.

Sibawaih, Imam, and Anita Tri Rahayu. "Analisis Pola Asuh Orang Tua Terhadap Gaya Belajar Siswa di Sekolah Menengah Atas Kharismawita Jakarta Selatan." Research and Development Journal of Education 3, no. 2 (2017).

Silberman, Melvin L. "Active Learning 101 Cara Belajar Siswa Aktif Edisi Revisi.” Bandung: Nuansa Cendekia, 2013.

Suryanto, Suryanto. "Meningkatkan Prestasi Belajar Pelajaran IPS Melalui Gabungan Metode Ceramah Dengan Metode Belajar Aktif Model Pengajaran Autentik." Jurnal Visi Ilmu Pendidikan 10, no. 2 (2018): 135146.

Tanaka, Ahmad. "Sistem Among, Dalton, dan Shanti Niketan Kajian Komparatif Historikal Sistem Pendidikan Indonesia, Amerika, dan India Serta Implikasinya Bagi Kemajuan Pendidikan di Indonesia Konteks Kekinian.” Jurnal Teknologi Pendidikan Madrasab 1, no. 1 (2018): 53-73.

Unaradjan, Dominikus Dolet. Metode Penelitian Kuantitatif. (Jakarta: Penerbit Unika Atma Jaya 2019).

Wardani, Rizqia. "Pengaruh Gaya Belajar, Kesiapan Belajar, dan Kemampuan Numerik Terhadap Prestasi Belajar Matematika Siswa SMP.” EkuivalenPendidikan Matematika 30, no. 1 (2017).

Warsah, Idi. "Implementasi Nilai Kepedulian Sosial Dalam Pendidikan Karakter Melalui Interaksi Sosial.” Jurnal Fakultas Agama Islam 9, no. 2 (2014).

. "Pendidikan Keimanan Sebagai Basis Kecerdasan Sosial Peserta Didik: Telaah Psikologi Islami.” Psikis: Jurnal Psikologi Islami 4, no. 1 (2018): 116.

-. "Religious Educators: A Psychological Study of Qur'anic Verses Regarding al-Rahmah.” AL QUDS : Jurnal Studi Alquran Dan Hadis 4, no. 2 (November 12, 2020): 275-98. https://doi.org/10.29240/alquds.v4i2.1762.

Warsah, Idi, Asri Karolina, and Yesa Satriya Dwi Hardiyanti. "Sense Of Humor Relevansinyaterhadap Teaching Style (Telaah Psikologi Pendidikan 
Islam)." Ar-Risalab: Media Keislaman, Pendidikan Dan Hukum Islam 18, no. 2 (2020): 247-267.

Warsah, Idi, and Nuzuar Nuzuar. "Analisis Inovasi Administrasi Guru Dalam Meningkatkan Mutu Pembelajaran (Studi Man Rejang Lebong)." Edukasi 16, no. 3 (2018): 294572.

Warsah, Idi, and Muhamad Uyun. "Kepribadian Pendidik: Telaah Psikologi Islami." Psikis: Jurnal Psikologi Islami 5, no. 1 (June 18, 2019): 62-73. https://doi.org/10.19109/Psikis.v5i1.3157.

Warsita, Bambang. "Teori Belajar Robert M. Gagne dan Implikasinya Pada Pentingnya Pusat Sumber Belajar." Jurnal Teknodik 12, no. 1 (2018): 064 078.

Wibowo, Nugroho. "Upaya Peningkatan Keaktifan Siswa Melalui Pembelajaran Berdasarkan Gaya Belajar di SMK Negeri 1 Saptosari." Elinvo (Electronics, Informatics, and Vocational Education) 1, no. 2 (2016): 128-139.

Yuliana, Lisa, Ikbal Barlian, and Riswan Jaenudin. "Pengaruh Model Pembelajaran Kooperatif Tipe Inside Outside Circle Terhadap Keaktifan Belajar Peserta Didik Pada Mata Pelajaran Ekonomi Kelas X Di SMA Srijaya Negara Palembang." Jurnal PROFIT Kajian Pendidikan Ekonomi Dan Ilmu Ekonomi 5, no. 1 (2018): 17-27.

Zahara, Zahara. "Upaya Meningkatkan Hasil Belajar Siswa Melalui Penerapan Model Discovery Learning Pada Materi Komposisi Fungsi dan Invers." Jurnal Kinerja Kependidikan (KKK) 1, no. 1 (2019): 88-104. 
242 | Belajea: Jurnal Pendidikan Islam, Vol. 5, No. 2, 2020 